\title{
Moja droga do Wrocławia
}

\author{
JULIAN KOBECKI
}

Nazywam się Julian Kobecki, jestem synem Awenira i Weroniki. Urodziłem się w Trokach, wychowywałem i dorastałem w Wilnie. Na pytanie „skąd jesteś?” od bardzo dawna odpowiadam: „z Wrocławia”.

Wrocław, Wielka Wyspa, Sępolno, kiedyś Uhu Strasse, później ulica Szenwalda, a teraz Płk. Józefa Becka - tu mieszkam. Mam 83 lata, siedzę w fotelu i wracam pamięcią do czasów, kiedy rozpocząłem wędrówkę do tego miasta.

Był rok 1944. Mieszkałem z moja mamą i siostrą Lusią oraz jej maleńką córeczką Walą Jutkiewicz w Wilnie przy ulicy Tartaki tuż obok mostu Zwierzynieckiego. Zbliżał się front. Słychać było już kanonadę. Obawialiśmy się nalotów. Most, obok którego mieszkaliśmy mógł stać się ważnym celem. Postanowiliśmy udać się do spokojnych, bezpiecznych Trok. Zapakowaliśmy Walę i możliwie dużo rzeczy do dziecięcego wózka. Objuczyliśmy jedyny rower paroma tobołkami. Wyruszyliśmy rankiem. Z perspektywy wielu lat mogę zaryzykować tezę, że wtedy właśnie rozpoczęła się moja podróż do Wrocławia (wtedy Breslau), miasta, o którym wówczas chyba nawet nie słyszałem. Wieczorem dotarliśmy do wsi Waka. Noc spędziliśmy w stodole na sianie. Następnego dnia dotarliśmy do Trok. Zamieszkaliśmy w domu Kobeckich. Przewalił się front. Dzisiaj trudno mi powiedzieć, kto pojechał na rowerze do Wilna. Mógł to być mój starszy brat Jurek lub szwagier, Józek Jutkiewicz (Agronom). Rekonesans przyniósł tragiczne wieści. Dom przy ulicy Tartaki został zbombardowany i spłonął. Na zgliszczach pozostały jedynie sterczące kominy. Cały dorobek, wszystko, co posiadaliśmy, z dokumentami i pamiątkami rodzinnymi włącznie, doszczętnie spłonęło. Nie było dokąd wracać. Pozostaliśmy w Trokach.

Podjąłem pracę w oddziale łączności, który zapewniał kontakt telefoniczny i telegraficzny z Wilnem i wsiami powiatu trockiego. Początkowo pracowałem jako monter. Znajomość litewskiego i rosyjskiego zapewniła mi awans na stanowisko zastępcy kierownika. Moim szefem był Litwin, który nie mówił po rosyjsku, a podwładnymi chłopskie dzieciaki ze Starych Trok. Ta fucha chroniła przed powołaniem do wojska. Możecie sobie wyobrazić, jakie to było korupcjogenne? Codziennie byłem obłaskawiany słoniną i samogonem, który obowiązkowo trzeba było wypić. Czorty z bimbrem. Ta słonina była wtedy najważniejsza. Oj, działo się, działo. 
Administracja załatwiła przewoźny projektor kinowy. Wraz z moim serdecznym kolegą Szurką (Aleksander Zajączkowski) zaczęliśmy wieczorami wyświetlać filmy w trockim kinie. Z czasem pojawił się gazik - samochód do obsługi wsi całego powiatu trockiego. Byłem kinomechanikiem i szoferem zarazem. Puszczaliśmy we wsiach filmy. Podejmowano nas bardzo gościnnie. Sołtysi i czynnik partyjny („парторг”) karmili i oczywiście poili. Nieważne, że byłem kierowcą. Alkomatów wówczas nie było. Zdarzało się, że milicja zabierała papiery samochodu, ale raczej ze względu na dramatyczny stan techniczny, aniżeli stan ducha kierowcy.

Praca w propagandzie miała w tej kwestii swoje dobre strony - na polecenie komitetu partii milicja zwracała zatrzymane wcześniej dokumenty i ruszałem w kolejny objazd.

Ten stan rzeczy, czyli codzienne popijawy, bardzo niepokoiły moją mamę. To ona miała zasadniczy wpływ na decyzję o repatriacji. Korzystając ze znajomości z pewnym wójtem otrzymałem zaświadczenie, że jestem narodowości polskiej i mieszkańcem zacnej mieściny Rudziszki. W Trokach nie byliśmy w stanie tego załatwić. Dostaliśmy się do ostatniego transportu. Naszym celem był zachód. Od Ziny Firkowicz wiedzieliśmy, że Józef Firkowicz jest dyrektorem cukrowni na Dolnym Śląsku w Otmuchowie. Ruszyliśmy praktycznie bez bagażu bo jak wcześniej wspomniałem, wojna skutecznie pozbawiła nas dóbr materialnych. Józef Firkowicz zaopiekował się nami. Dostałem pracę elektryka w odbudowującej się cukrowni Baworów. Moja mama pojechała na rozpoznanie do Wrocławia. Zatrzymała się wśród swojaków na Sępolnie.

To było w 1946 roku. Remont cukrowni, w której pracowałem, dobiegł końca. Zakończyła się też kampania cukrownicza. Dostałem deputat w postaci 100 kilogramów cukru - poważny wówczas majątek. Z tym słodkim bagażem przyjechałem do Wrocławia. Zamieszkaliśmy przy ulicy Kasprzaka na Sępolnie. Z ogłoszeń dowiedziałem się, że organizowane są 4-miesięczne kursy przygotowawcze do egzaminu wstępnego do Technikum Budowlanego. Miałem ukończone 3 klasy gimnazjum wileńskiego. Kurs poszedł gładko. Zdałem celująco egzamin do Technikum Elektrycznego. Pomoc mamy i deputat cukrowy pozwoliły na ukończenie 1 . roku w trybie dziennym. W kolejnym musiałem pomyśleć o pracy. Pomógł mi w tym pracujący w NBP Michał Firkowicz (brat Józefa), osiadły we Wrocławiu. Zatrudniłem się w Dolmelu. Matura, potem praca w Pafawagu, rodzina, studia, Elwro. Moje życie na trwale związane jest z Wrocławiem.

Sępolno to wyjątkowe wrocławskie osiedle. Zaprojektowano je z myślą o olimpiadzie, która miała odbyć się 1940 roku. Jest ono urzeczywistnieniem idei miasta-ogrodu. Pięknie tu. Na Sępolnie mieszkało wielu Karaimów. Oprócz nas i Państwa Łopatto sąsiadami byli Robaczewscy, Dubińscy. Przy Monte Casino mieszkał Józef Firkowicz z żoną Lidią (prawosławną) i synami Tolkiem, Jurkiem i Gabrielem. Pamiętam panią Kobecką wraz z córką i synem. Studenckie lata spędzili tu Sławek Pilecki i Aleksander Nowicki. Wrocławscy Karaimi (ci z Trok, Łucka i Halicza) spotykali się w czasie świąt u Abkowiczów. Tu przyszły na świat ich dzieci i wnuki, które o Wrocławiu mówią: „nasze miasto”. 